\title{
Strength assessment of rice hills from different planting distance by loading simulation
}

\author{
Edi Santosa*, Herdhata Agusta, Dwi Guntoro, and Sofyan Zaman \\ Department of Agronomy and Horticulture, Faculty of Agriculture, IPB University \\ Jl. Meranti Kampus IPB Darmaga, Bogor 16680, Indonesia \\ *Corresponding author: edisang@gmail.com
}

Received: 02 ${ }^{\text {nd }}$ January 2018; Revised: 10 ${ }^{\text {th }}$ April 2020; Accepted: $23^{\text {rd }}$ April 2020

\section{Keywords:}

Double row spacing, extreme weather, lodging simulation, strong wind, weight holding capacity

\begin{abstract}
Plant spacing arrangement might benefit hill strength from the impact of strong wind velocity during extreme weather situations. Here, a loading test to evaluate rice hill strength was performed on Ciherang variety grown in square and double row spacing 2:1. The research was conducted at Cilubang village, Dramaga, Bogor, West Java, Indonesia from March to May 2017. Weight holding capacity was evaluated in 85 days after transplanting on four levels of hill height, i.e., $80 \mathrm{~cm}, 60 \mathrm{~cm}, 40 \mathrm{~cm}$, and $20 \mathrm{~cm}$ above soil level with threetime replication. The results showed that double-spaced hills had $66.0 \% \pm 3.1 \%$ stronger than those of square spacing at all height measurement. To lodge a hill into $20 \mathrm{~cm}$ to $40 \mathrm{~cm}$ from soil level, it required $346.7 \mathrm{~g}$ to $741.7 \mathrm{~g}$ in square spacing, and $555.2 \mathrm{~g}$ to $1149.2 \mathrm{~g}$ in double row spacing. Stronger hills in double row spacing seemed to correlate with a higher number of tiller and hills architecture; it requires further study in the role of both factors on the hill strength improvement. The present study recommends applying double row spacing to improve rice hill strength especially at a time with a high chance of lodging by strong wind incident.
\end{abstract}

\section{INTRODUCTION}

Rice (Oryza sativa L.) is an important food in Asia, and the demand increases steadily in line with the increasing population. Consequently, lots of Asian governments are encouraged to sustain rice production (United Nations, 2017; International Rice Research Institute, 2019). However, in some areas, high cropping intensity increases the chance of rice plant to get the extreme weather impact, e.g., strong wind and heavy rainfall, causing physiological disorder and plant lodging. Strong wind velocity is a kind of abiotic stress, and it causes detriment to rice production through shreds leaves and rice grain shattering, and lodging (Baker et al., 2014; Sridevi and Chellamuthu, 2015; Gardiner et al., 2016; Martinez-Vazquez, 2016). In Indonesia, Santosa et al. (2016) estimate that annual rice loss due to lodging was about US\$ 270 million. Since the incident of the extreme weather tends to increase as the effect of climate change (Niu et al., 2016; Carvalho et al., 2017; Soares et al., 2017), lodging mitigation is important to sustain rice production.

Recently, double row spacing (jajar legowo) becomes popular in Indonesia to increase rice production (Ruminta et al., 2017) and facilitates integrated rice-fish cultivation (minapadi) (Mahmudiyah and Soedradjad, 2018). Adoption of double row spacing is also believed to reduce lodging incident from strong wind impact due to border effect. However, evaluation of the effect of planting distance on plant strength is limited. In this case, we assume that lodging is due to weak rice hill. It is well known that crop sensitivity to strong wind impact and lodging is determined by wind speed, species, variety, growth stage, plant architecture, nutrient status, plant biometry and leaf orientation (Hayashi et al., 2011; Ishimaru et al., 2012; Selino 
and Jones, 2013; Sridevi and Chellamuthu, 2015; Tadrist et al., 2015; Martinez-Vazquez, 2016). According to Niu et al. (2016) combination between strong wind and heavy rainfall causes more marked damage in wheat.

Ideally, the measurement of the strong wind impact is conducted directly or inside a wind simulator (Cao et al., 2012; Cataldo et al., 2013; Zhu and Shao, 2017). However, access to such measurement is technically difficult in developing countries. Moreover, the characteristics of strong wind incident are local, temporal and unpredictable (Santosa et al., 2016). Fortunately, some authors have developed indirect methods, e.g., mechanical load (Niu et al., 2012), tree pulling (Kane and Clouston, 2008), digital measurement (James and Kane, 2008), torsion (Virot et al., 2016), and electrical measurement (Wu and Ma, 2016). According to Gan and Salim (2014), the wind has velocity (kinetic power) and pressure (potential power) characteristics. Therefore, those indirect methods mostly work based on the critical point of breakage due to bending which exceeds the rupture modulus of the material (Mochida et al., 2008; Gan and Salim, 2014; Virot et al., 2016).

Here, the strength of rice hills of different planting distance is contrasted using indirect method and it is expressed in weight holding capacity (WHC); high WHC means less lodged. The concept of WHC refers to Muthu and Li (2014) with modification for rice hills, i.e., the maximum amount of load hills bears

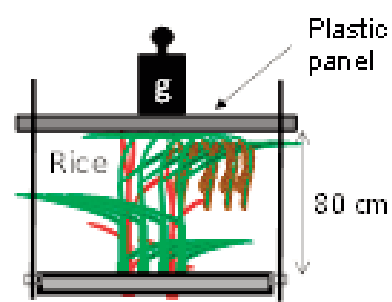

(a) $80 \mathrm{~cm}$

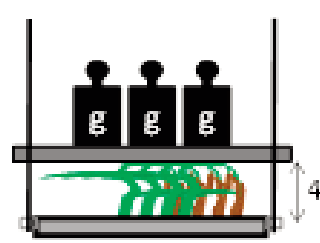

(c) $40 \mathrm{~cm}$

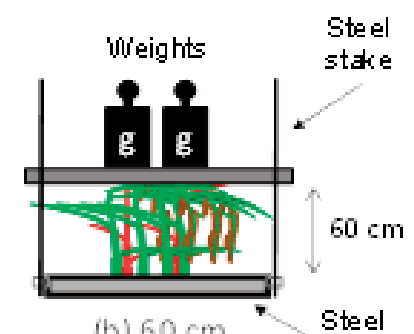

(b) $60 \mathrm{~cm}$ frame
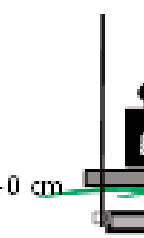

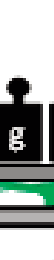

(d) $20 \mathrm{~cm}$

Figure 1. Loading simulation to estimated weight holding capacity. (a)-(d) Scheme of panel penetration to hills at $80 \mathrm{~cm}, 60 \mathrm{~cm}, 40 \mathrm{~cm}$, and $20 \mathrm{~cm}$ from soil level, respectively.

for a fixed amount of time and can be recorded. The objective of the experiment was to evaluate the effect of different planting distances on hill strength of Ciherang as leading rice variety in Indonesia.

\section{MATERIALS AND METHODS}

The research was conducted during the rainy season in farmer field at Cilubang village Dramaga (240 m above sea level), Bogor District, West Java, Indonesia from March-May 2017. Average temperature and relative air humidity during the research were $28^{\circ} \mathrm{C}$ to $32^{\circ} \mathrm{C}$ and $65 \%$ to $72 \%$, respectively. Soil was harrowed twice by incorporating rice straw from the previous harvest. Ciherang seedling aged 20 days after showing was planted on 11 March 2017 with two seedlings per hole.

The treatment consisted of two factors, i.e., plant spacing (square/ubinan; $20 \mathrm{~cm} \times 20 \mathrm{~cm}$ and double row spacing/legowo $2: 1 ; 30 \mathrm{~cm} \times[20 \mathrm{~cm} \times$ $15 \mathrm{~cm}])$ as main plot and loading height $(80 \mathrm{~cm}, 60$ $\mathrm{cm}, 40 \mathrm{~cm}$ and $20 \mathrm{~cm}$ from soil level) as sub plot. Sub plot sized $2.5 \mathrm{~m} \times 2.5 \mathrm{~m}$; a main plot sized 200 $\mathrm{m}^{2}$ including border plants.

Loading simulation was conducted on 25 May 2017 or 85 days after transplanting (DAT). The simulation followed the concept of Niu et al. (2012) with modification. Time of treatment was determined according to the initial critical stage for lodging by Sridevi and Chellamuthu (2015). Plastic panel was
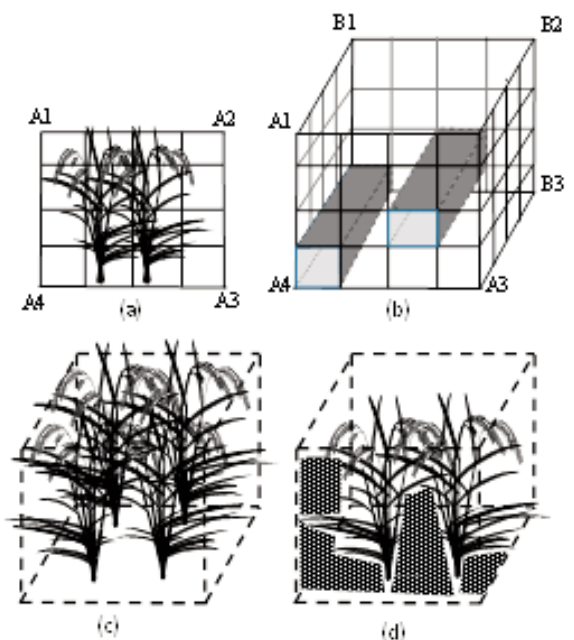

Figure 2. Steps to estimated free space around rice hills. (a) Two dimension hills projection used $10 \mathrm{~cm} \times 10 \mathrm{~cm}$ grids. (b) Three-dimension projection to estimated free space (shaded). (c) Three-dimension with eight rice hills. (d) Estimation of free space (shaded). 
installed above rice hills and loaded gradually using weight until the panel reached height of $80 \mathrm{~cm}, 60 \mathrm{~cm}$, $40 \mathrm{~cm}$ and $20 \mathrm{~cm}$ from soil level (Figure 1). Data was obtained from three replications. One measurement covered eight rice hills, and then was averaged. The height level was determined based on the preliminary study. WHC of rice hill at each height level was recorded at steady height and expressed in gram per hill. Hill and tiller damage was evaluated.

Rice plant was maintained according to local practice. NPK fertilizers were applied at rate of 300 kg.ha- ${ }^{-1}$ urea $(46 \% \mathrm{~N}), 100 \mathrm{~kg} \cdot \mathrm{ha}^{-1} \mathrm{SP}-36\left(36 \% \mathrm{P}_{2} \mathrm{O}_{5}\right)$ and $100 \mathrm{~kg}^{2} \mathrm{ha}^{-1} \mathrm{KCl}\left(60 \% \mathrm{~K}_{2} \mathrm{O}\right)$. All phosphorus, all potassium, and two-thirds of nitrogen were applied at planting. The remaining one-thirds of $\mathrm{N}$ was applied at $3^{\text {rd }}$ week after transplanting. Water level was maintained $10-15 \mathrm{~cm}$ in height from planting to maximum grain filling stage at $80 \mathrm{DAT}$; and it was reduced gradually until harvest.

Available space around rice plant canopy was estimated following the method of Li et al. (2017) with major modification. Briefly, the hills were captured using camera. Then by using computer, the space around rice hills was delineated to determine the filled and free spaces (Figure 2). Shaded space by rice culm or leaves was considered as filled space, otherwise, it was empty one. To avoid complexity in drawing, spaces between culm and leaves, and between leaves less than $2 \mathrm{~cm}$ were simply considered as filled space. Space occupied by a single leaf was considered empty. Thus, the accuracy of the estimation was limited by these assumptions.

Data was evaluated using ANOVA, and any significance was further evaluated using the least significant different (LSD) at level of confident of $5 \%$.

\section{RESULTS AND DISCUSSIONS}

\section{Plant characteristics}

Ciherang variety in irrespective plant spacing produced 4-7 leaves with average of 4.4 leaves in each tiller. During the simulation time, most productive tillers had 2-4 green leaves and healthy culm, and the rice grains had fully developed irrespective of spacing treatments. On average, productive tiller from square spacing had 2.4 green leaves while double row spacing had 2.6 leaves, but they were statistically insignificant difference.

Plants from both square and double row spacing had similar height and stem diameter (Table 1). The plant from double row spacing had a higher number of tiller and productive tiller than that of the square one. The increasing number of tiller and productive tillers of rice planted in double row spacing has been reported (Erythrina and Zaini, 2014; Amanah et al., 2017; Ruminta et al., 2017).

Table 1. Ciherang variety properties from two plant spacing in 85 days after transplanting

\begin{tabular}{lccccc}
\hline \multirow{2}{*}{ Plant spacing } & \multirow{2}{*}{$\begin{array}{c}\text { Total plant } \\
\text { height }(\mathrm{cm})^{z}\end{array}$} & \multicolumn{2}{c}{$\begin{array}{c}\text { Plant height up Stem diameter } \\
\text { to flag leaf }(\mathrm{cm})\end{array}$} & \multicolumn{2}{c}{ Number of tiller per hill } \\
\cline { 4 - 6 } & & & & & \multicolumn{2}{c}{ Total } & Productive \\
\hline Square & $69.3 \pm 4.4 \mathrm{a}$ & $85.7 \pm 4.0 \mathrm{a}$ & $0.36 \pm 0.03 \mathrm{a}$ & $10.3 \pm 1.9 \mathrm{~b}$ & $9.6 \pm 1.3 \mathrm{~b}$ \\
Double row & $70.2 \pm 4.9 \mathrm{a}$ & $86.8 \pm 6.1 \mathrm{a}$ & $0.40 \pm 0.03 \mathrm{a}$ & $15.5 \pm 2.7 \mathrm{a}$ & $14.3 \pm 2.1 \mathrm{a}$ \\
\hline
\end{tabular}

Remarks: ${ }^{2}$ From soil level to neck of panicle; ${ }^{\mathrm{y}} \mathrm{At} 10 \mathrm{~cm}$ from soil level. Value followed by different alphabet was statistically different at $\operatorname{LSD} \alpha=5 \%$. Mean \pm SD

Table 2. Weight holding capacity (WHC) of Ciherang variety from square and double row spacing at different loading height from soil level

\begin{tabular}{lcccc}
\hline & \multicolumn{3}{c}{ WHC per hill (g) } \\
\cline { 2 - 5 } Plant spacing & $80 \mathrm{~cm}$ & $60 \mathrm{~cm}$ & $40 \mathrm{~cm}$ & $20 \mathrm{~cm}$ \\
\hline Square & $13.3 \pm 0.7 \mathrm{~b}$ & $221.5 \pm 72.8 \mathrm{~b}$ & $346.5 \pm 72.7 \mathrm{~b}$ & $741.7 \pm 36.1 \mathrm{~b}$ \\
Double row & $19.2 \pm 0.7 \mathrm{a}$ & $327.7 \pm 60.3 \mathrm{a}$ & $555.2 \pm 71.3 \mathrm{a}$ & $1149.2 \pm 118.4 \mathrm{a}$ \\
\hline
\end{tabular}

Remark: Value followed by different alphabet was statistically different at LSD $\alpha=5 \%$. Mean \pm SD 


\section{Hill and tiller strength}

Weight holding capacity (WHC) increased from upper part of hill to the lower part, irrespective of spacing treatment (Table 2). For example, a hill was able to hold $13.3 \mathrm{~g}$ for square spacing and $19.2 \mathrm{~g}$ for double row spacing when plastic panel reached the height of $80 \mathrm{~cm}$ from soil level, and was able to hold $741.7 \mathrm{~g}$ and $1149.2 \mathrm{~g}$ respectively when the panel reached the height of $20 \mathrm{~cm}$ from soil level. Doublespaced plants produced stronger tiller, irrespective height from soil level. In average it hold $66.0 \% \pm 3.1 \%$ more in weight than that of square spacing. Increasing WHC was more markedly at height of $80 \mathrm{~cm}$ and 60 $\mathrm{cm}$, i.e., $69.3 \%$ and $67.6 \%$, respectively, than at height of $40 \mathrm{~cm}(62.4 \%)$ and $20 \mathrm{~cm}$ (64.5\%) although statistically they had no significant difference.

Increasing WHC from double-spaced hills was likely related to number of tiller and its' architecture. Double-spacing produced tiller of $33.5 \%$ and productive tiller per hill of $32.9 \%$ which was higher than square spacing (Table 1). The higher number of productive tiller at double-spaced planting system was inline with previous findings (Ikhwani, 2015; Magfiroh et al., 2017). It is probably that double-spacing leading all hills plays as the edge rows that commonly express superior growth in rice.
The presence of unproductive tiller presumably contributed to strength especially at hill base. It was confirmed within a treated plot that some hills with higher number of unproductive tillers had less severe damage than the hills without unproductive tiller. Table 3 shows that double row spacing stimulated growth of unproductive tillers, e.g., $33.3 \%$ to $75.0 \%$ higher. It needs further verification on the contribution of unproductive tiller on hill strength.

There was difference on canopy width and space among spacing treatments (Table 3 ). In average, double-spaced hills had canopy width of $18.5 \%$ and free space of $12.5 \%$ to $30.8 \%$ which was higher than the square one. It is probable that double-spaced hills received higher light intensity than those hills of square-spacing. The indication for double-spaced land receiving higher light intensity was confirmed by Rianto et al. (2019), where average weed investment around hills of double-spacing is higher than that around square-spacing. According to Restrepo and Garcés (2013) unshaded rice plants have about 33\% higher photosynthetic rate than that of the shaded one. Unfortunately, light intensity and photosinthetic rate were not measured in present experiment.

Conversely, square-spacing had $13-37 \%$ denser canopy that might restrict the wind velocity, unlike hills of double-spacing that might have more aero-

Table 3. Canopy characteristics of Ciherang variety from different plant spacing

\begin{tabular}{lccc}
\hline Plant spacing & $\begin{array}{c}\text { Canopy width } \\
(\mathrm{cm})^{z}\end{array}$ & $\begin{array}{c}\text { Empty space } \\
\text { around plant } \\
\text { canopy }(\%)^{\mathrm{y}}\end{array}$ & $\begin{array}{c}\text { Number of } \\
\text { unproductive tiller } \\
(<20 \mathrm{~cm})\end{array}$ \\
\hline Square & $48-62 \mathrm{~b}$ & $35-45 \mathrm{~b}$ & $0-2 \mathrm{~b}$ \\
Double row & $59-76 \mathrm{a}$ & $40-65 \mathrm{a}$ & $3-8 \mathrm{a}$
\end{tabular}

Remarks: ${ }^{2}$ Measured from outer leaf or panicle projection. ${ }^{\mathrm{y}}$ Estimated using computer drawing. Value followed by different alphabet was statistically different at LSD $\alpha=5 \%$.

Table 4. Average weight holding capacity (WHC) per tiller of Ciherang variety from square and double row plant spacing at different loading heighst from soil level

\begin{tabular}{lcccc}
\hline \multirow{2}{*}{ Plant spacing } & \multicolumn{4}{c}{ WHC per tiller $(\mathrm{g})^{2}$} \\
\cline { 2 - 5 } & $80 \mathrm{~cm}$ & $60 \mathrm{~cm}$ & $40 \mathrm{~cm}$ & $20 \mathrm{~cm}$ \\
\hline Square & $1.3 \pm 0.2 \mathrm{a}$ & $22.8 \pm 10.3 \mathrm{a}$ & $35.2 \pm 12.4 \mathrm{a}$ & $74.0 \pm 16.0 \mathrm{a}$ \\
Double row & $1.3 \pm 0.2 \mathrm{a}$ & $21.2 \pm 0.5 \mathrm{a}$ & $36.2 \pm 3.9 \mathrm{a}$ & $74.9 \pm 6.5 \mathrm{a}$ \\
\hline
\end{tabular}

Remarks: ${ }^{2}$ ncluding productive and unproductive tiller. Value followed by similar alphabet was statistically similar at $\operatorname{LSD} \alpha=5 \%$. Mean \pm SD. 
dynamic in case of wind velocity. As the results, speare-spacing was prone to lodging. In steady wind, Hong et al. (2002) stated that wind speed decreases to upper half and the speed tends to increase from the lower half of the canopy towards the ground. From Table 3, it was expected that double-spaced hills had lower turbulence which resulted in less prone to strong wind impact. However, ifurther verification by using real wind simulator is needed.

Interestingly, WHC value per tiller did not show any significant difference among spacing treatments (Table 4). At the height of $20 \mathrm{~cm}$ to $60 \mathrm{~cm}$ from soil level, tillers from double row spacing had more uniform responses to weight treatment than those from square spacing; as expressed by lower standard deviation of WHC value in double row spacing. It means that determination using WHC value on the basis of number of tiller solely could be underestimated. Further analysis by excluding unproductive tiller revealed a sharp increase in WHC value for both spacing at the height of $20 \mathrm{~cm}$ to $40 \mathrm{~cm}$ from soil level (Figure 3). It was indicated that there was substantial contribution of unproductive tiller to WHC value in present experiment. On the other side, low WHC value at $80 \mathrm{~cm}$ in height was due to difficulty in loading treatment because it was nearly the same as the plant height. Table 1 shows that hills had $85.7 \mathrm{~cm}$ to $86.8 \mathrm{~cm}$ in height including flag leaf. It is interesting to evaluate hill strength using rice genotype with different height characteristics.

\section{Hills damage and its implication}

Loading treatment predominantly caused rice hills damage. A hill of square spacing required load of $741.7 \mathrm{~g}$ to complete damage/lodging while double-spaced hills required $1149.2 \mathrm{~g}$ (Table 2). However, the damage part of hill depends on the loading level (Table 5). In some cases, initially hills bended down before completely being lodged or broken. Loading up to $80 \mathrm{~cm}$ predominantly caused

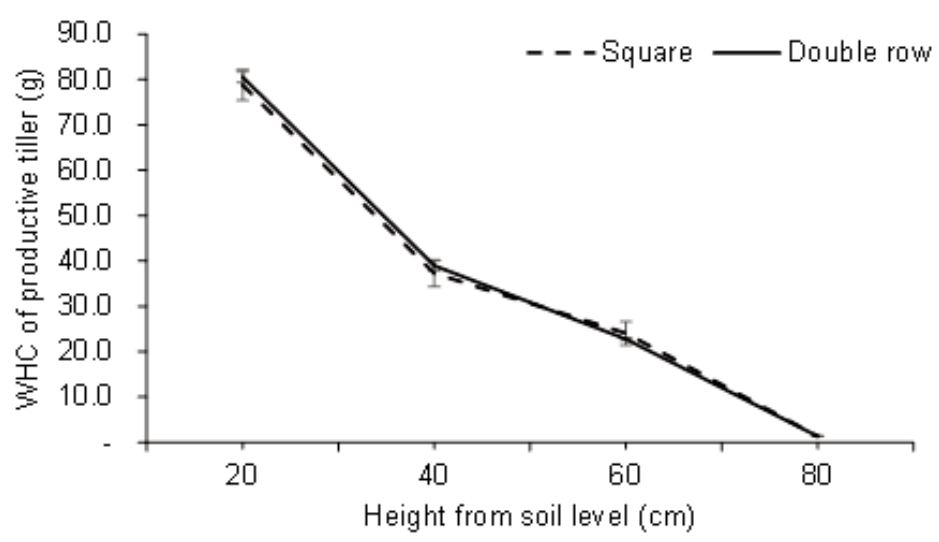

Figure 3. Weight holding capacity (WHC) of a productive tiller from square and double row spacing at different height from soil level. Mean \pm SE

Table 5. The damage as the effect of loading at different height on Ciherang variety from square and double row spacing

\begin{tabular}{|c|c|c|c|c|}
\hline \multirow{2}{*}{ Plant spacing } & \multicolumn{4}{|c|}{ Loading height treatment from soil level } \\
\hline & $80 \mathrm{~cm}$ & $60 \mathrm{~cm}$ & $40 \mathrm{~cm}$ & $20 \mathrm{~cm}$ \\
\hline Square & Panicle & $\begin{array}{l}\text { Panicle; } 3^{\text {rd }} \text { and } 4^{\text {th }} \\
\text { internode from top }\end{array}$ & $\begin{array}{l}\text { Panicle; } 3^{\text {rd }}, 4^{\text {th }} \text { and } \\
5^{\text {th }} \text { internode from } \\
\text { top }\end{array}$ & $\begin{array}{c}\text { Panicle; } 2^{\text {nd }}, 3^{\text {rd }}, 4^{\text {th }} \text { and } 5^{\text {th }} \\
\text { internode; } 2^{\text {nd }} \text { and } 3^{\text {rd }} \text { node; } \\
\text { and internode close to soil } \\
\text { level }\end{array}$ \\
\hline Double row & Panicle & $\begin{array}{l}\text { Panicle; } 2^{\text {nd }} \text { and } 3^{\text {rd }} \\
\text { internode from top }\end{array}$ & $\begin{array}{l}\text { Panicle; } 3^{\text {rd }}, 4^{\text {th }} \text { and } \\
5^{\text {th }} \text { internode from } \\
\text { top }\end{array}$ & $\begin{array}{l}\text { Panicle; } 2^{\text {nd }}, 3^{\text {rd }}, 4^{\text {th }} \text { and } 5^{\text {th }} \\
\text { internode; and } \\
\text { internode close to soil level }\end{array}$ \\
\hline
\end{tabular}




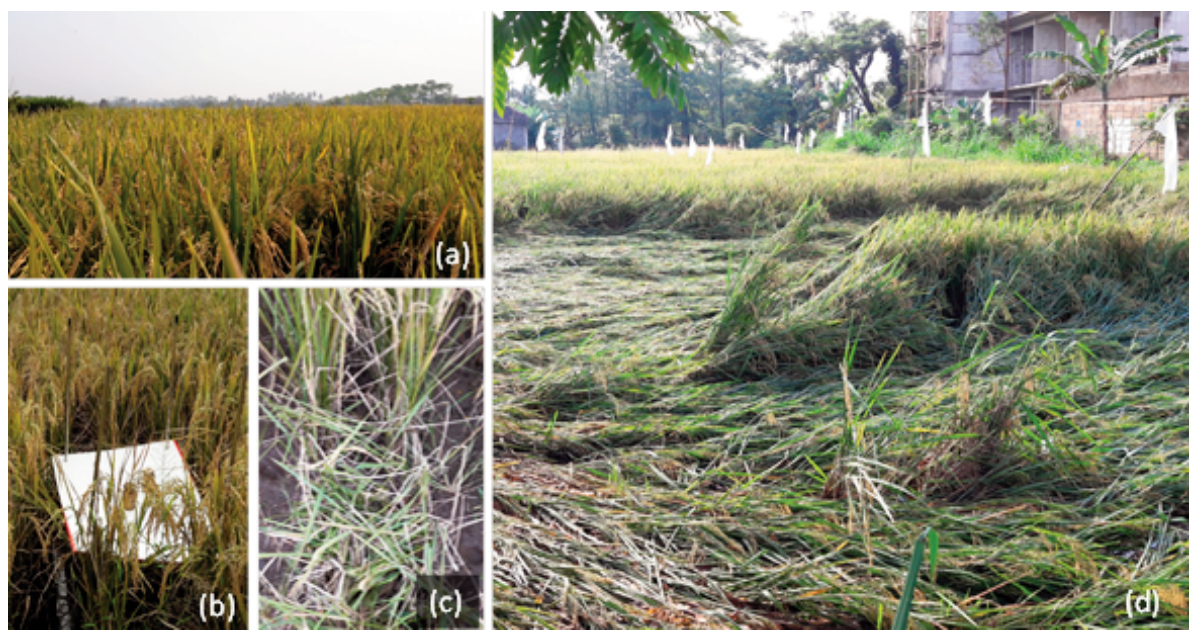

Figure 4. Rice hill before and after loading, and lodging by strong wind. (a) Hills before treatment. (b) Loading at $60 \mathrm{~cm}$ from soil level. (c) Straw breakage after loading up to $20 \mathrm{~cm}$ from soil level. (d) Inpari 30 got lodged after wind impact in Cilubang Village on 10 Nov, 2017.

minor panicle rupture. Additional loading up to height of 60 and $40 \mathrm{~cm}$ from soil level stimulated $2^{\text {nd }}-5^{\text {th }}$ internodes break accompanied by panicle damage. Breakage position of internode seemed random, but upper internodes tended to break earlier than the lower ones. Rice culm pointed from lower to upper part might be the reason why upper internodes were broken earlier at loading treatment. It is important to note that hills without unproductive tiller expressed more severe damage when plastic panel penetrated until $20 \mathrm{~cm}$ from soil level. Santosa et al. (2016) and Dulbari et al. (2018) pointed out that $0-20 \mathrm{~cm}$ or $0-40 \mathrm{~cm}$ from soil level is the most sensitive to strong wind impact. In the future, role of basal tiller strength should be further considered in rice genotype improvement, in addition to agronomic manipulation through application of silicate (Ahmad et al., 2013).

It is noted that hill damage after weight application contrasted to natural hill damaged by strong wind impact (Figure 4). Hills damage from loading treatment showed irregular pattern (Figure 4c) while it had particular pattern after natural wind impact (Figure 4d). Indeed, wind characteristic in the natural condition could be more complex than the simplification in the loading simulation. In the incident of rice lodging, wind pressure is likely the most important (Gan and Salim, 2014). In general, damage pattern from present simulation could be overestimated as the comparison to natural incident of lodging although such damage pattern has been observed by Santosa et al. (2016). Nevertheless, evaluation using WHC could be the initial screening tools for hill strength in reference to lodging tolerant genotype in the near future. Improvement tools on WHC measurement is needed.

According to the owner of rice field in Figure 4d, the Inpari 30 variety was planted in double row spacing. In the field, plant spacing might not be the only factor that determines lodging incidentas other causes have been mentioned by previous authors (Mochida et al., 2008; Hayashi et al., 2011; Selino and Jones, 2013; Tadrist et al., 2015; Barnard and Bauerle, 2016). Therefore, it is interesting to study rice canopy morphology that determines sturdiness under strong wind impact.

We speculated that in reference to strong wind adaptation, contribution of unproductive tiller and plant aerodynamic is important. Unproductive tiller mostly stay green at later stage of rice maturity, and could play as additional stake for the productive tillers from lodging at the weakest position to break, which was $0 \mathrm{~cm}$ to $40 \mathrm{~cm}$ from soil level. It was noted that most unproductive tillers sized $20 \mathrm{~cm}$ in height. In this preliminary finding, we speculated that the existence of high unproductive tillers under double row spacing became key factor in hill strength. Nevertheless, it is generally concluded that large number of unproductive tiller competes with final rice production (Wang et al., 2007; Badshah et al., 2014; Reuben et al., 2016). Therefore, it needs further evaluation by using larger number of rice 
genotypes to reveal the role of unproductive tiller andhill aerodynamic, and to figure out reasonable number of unproductive tiller.

\section{CONCLUSIONS}

Double row spacing improved hills strength by $62.4-69.3 \%$ (66.0 $3.1 \%$ on average) than square spacing in Ciherang variety. Increasing the strength of double-spaced hills was related to number of tiller and free space around the hills. It was likely that presence of unproductive tiller contributed to enhance hill strength especially at the height of 0-40 $\mathrm{cm}$ from soil level. Thus, it is recommended to plant Ciherang variety using double row spacing to enhance hill strength against strong wind velocity. In the future, it is interesting to study effect of spacing on the hill strength using genotypes with different canopy morphology in order to develop better loging resistant.

\section{ACKNOWLEDGMENTS}

The authors would like to thank Ministry of Research Technology and Higher Education from Republic of Indonesia for financial support under the scheme of Competitive Grant (Hibah Kompetisi) for FY 2016-2018 and Mr. Anis from Cilubang Village for the field support.

\section{REFERENCES}

Ahmad, A., M. Afzal, A. U. H. Ahmad, and M. Tahir. 2013. Effect of foliar application of silicone on yield and quality of rice (Oryza sativa L.). Cercetari Agronomice in Moldova, 46: 23-28.

Amanah, A., S. N. H. Utami, and M. Nurudin. 2017. Effect of planting distance on nitrogen uptake and productivity of paddy var. Rojolele irradiated with gamma rays in Inceptisol. IImu Pertanian (Agricultural Science), 2: 070-078.

Badshah, M. A., N. Tu, Y. Zou, M. Ibrahim, and K. Wang. 2014. Yield and tillering response of super hybrid rice Liangyoupeijiu to tillage and establishment methods. The Crop Journal, 2: 79-86.

Baker, C. J., M. Sterling, and P. Berry. 2014. A generalized model of crop lodging. Journal of Theoretical Biology, 363: 1-12.
Barnard, D. M. and W. L. Bauerle. 2016. Seasonal variation in canopy aerodynamics and the sensitivity of transpiration estimates to wind velocity in broadleaved deciduous species. Journal of Hydrometeorology, 17: 3029-3043.

Cao, J., Y. Tamura and A. Yoshida. 2012. Wind tunnel study on aerodynamic characteristics of shrubby specimens of three tree species. Urban Forest \& Urban Greening, 11: 465-476.

Carvalho, D., A. Rocha, M. Gómez-Gesteira, and C. S. Santos. 2017. Potential impacts of climate change on European wind energy resource under the CMIP5 future climate projections. Renewable Energy, 101: 29-40.

Cataldo, J., V. Durañona, R. Pienika, P. Pais, and A. Gravina. 2013. Wind damage on citrus fruit study: Wind tunnel tests. Journal of Wind Engineering and Industrial Aerodynamics, 116: 1-6.

Dulbari, E. Santosa, Y. Koesmaryono, and E. Sulistyono. 2018. Pendugaan kehilangan hasil pada tanaman padi rebah akibat terpaan angin kencang dan curah hujan tinggi. Jurnal Agronomi Indonesia, 46: 17-23.

Erythrina and Z. Zaini. 2014. Budi daya padi sawah sistem tanam jajar legowo: Tinjauan metodologi untuk mendapatkan hasil optimal. Jurnal Penelitian dan Pengembangan Pertanian, 33: 79-86.

Gan, C. J. and S. M. Salim. 2014. Numerical analysis of fluid-structure interaction between wind flow and trees. Proceeding of the World Congress on Engineering, 2: 1218-1223

Gardiner, B., P. Berry and B. Moulia. 2016. Review: Wind impacts on plant growth, mechanics and damage. Plant Science, 245: 94-118.

Hayashi, K., M. Tatuno, H. Nagabayashi, H. Hasimoto, and T. Tada. 2011. Fluid forces acting on a tree. Journal of Japan Society of Civil Engineers Ser. A2 (Applied Mechanics (AM)), 67: 569-580.

Hong, J., J. Kim, A. Miyata, and Y. Harazono. 2002. Basic characteristics of canopy turbulence in a homogeneous rice paddy. Journal of Geophysical Research, 107: 801-820.

Ikhwani. 2015. Effects of interaction between new rice varieties and plant spacing to productivity of rice. Informatika Pertanian, 24: 245-256.

International Rice Research Institute. 2019. Sustainable rice landscapes initiative to reduce environmental footprint of rice production. https: //www. irri.org/news-and-events/news/. 
Ishimaru, T., H. Hirabayashi, T. Kuwagata, T. Ogawa, and M. Kondo. 2012. The early-morning flowering trait of rice reduces spikelet sterility under windy and elevated temperature conditions at anthesis. Plant Production Science, 15: 19-22.

James, K. and B. Kane. 2008. Precision digital instruments to measure dynamic wind loads on trees during storms. Agricultural and Forest Meteorology, 148: 1005-1061.

Kane, B. and P. Clouston. 2008. Tree pulling tests of large shade trees in the genus Acer. Arboriculture \& Urban Forest, 34: 101-109.

Li, X., X. Wang, H. Wei, X. Zhu, Y. Peng, M. Li , T. Li, and $\mathrm{H}$. Huang. 2017. A technique system for the measurement, reconstruction and character extraction of rice plant architecture. PLOS ONE, 12: 1-19.

Magfiroh, N., I.M. Lapanjang, and U. Made. 2017. Pengaruh jarak tanam terhadap pertumbuhan dan hasil tanaman padi (Oryza sativa L.) pada pola jarak tanam yang berbeda dalam sistem tabela. Agrotekbis, 5: 212-221.

Mahmudiyah, E. and R. Soedradjad. 2018. Pengaruh pupuk organik dan teknik budidaya terhadap produksi padi dan ikan pada sistem mina padi. Agritrop, 16: 17-37.

Martinez-Vazquez, P. 2016. Crop lodging induced by wind and rain. Agricultural and Forest Meteorology, 229: 265-275.

Mochida, A., Y. Tabata, T. Iwata, and H. Yoshino. 2008. Examining tree canopy models for CFD prediction of wind environment at pedestrian level. Jornal of Wind Engineering \& Industrial Aerodynamics, 96: 1667-1677.

Muthu, S. S. and Y. Li. 2014. Assessment of functional aspects of shopping bags, p. 55-76. In: Muthu, S. S. and Y. Li. Assessment of environmental impact by grocery shopping bags. Singapore: EcoProduction, Springer.

Niu, L. Y., S. W. Feng, Z. G. Ru, G. Li, Z. P. Zhang, and Z. W. Wang. 2012. Rapid determination of single-stalk and population lodging resistance strengths and an assessment of the stem lodging wind speeds for winter wheat. Field Crops Research, 139: 1-8.

Niu, L. Y., S. W. Feng, W. Ding, and G. Li. 2016. Influence of speed and rainfall on large-scale wheat lodging from 2007 to 2014 in China. PLOS ONE, 11: e0157677.
Restrepo, H. and G. Garcés. 2013. Evaluation of low light intensity at three phenological stages in the agronomic and physiological responses of two rice (Oryza sativa L.) cultivars. Agronomia Colombiana, 31: 195-200.

Reuben, P., F. C. Kahimba, Z. Katambara, H. F. Mahoo, W. Mbungu, F. Mhenga, A. Nyarubamba, and M. Maugo. 2016. Optimizing plant spacing under the systems of rice intensification (SRI). Agricultural Sciences, 7: 270-278.

Rianto, D. F., D. Guntoro, and E. Santosa. 2019. Weed growth and lowland rice production as affected by planting patterns and rice varieties. Journal of Tropical Crop Science, 6: 67-75.

Ruminta, A. Wahyudin, and S. Sakinah. 2017. Respon pertumbuhan dan hasil tanaman padi terhadap jarak tanam pada lahan tadah hujan dengan menggunakan pengairan intermittent. Agrin, 21: 46-58.

Santosa, E., Dulbari, H. Agusta, D. Guntoro, and S. Zaman. 2016. Fenomena tanaman rebah dan implikasinya pada perbaikan varietas padi adaptif cuaca ekstrim di Indonesia. Prosiding Seminar Nasional PERIPI 'Strategi Pemuliaan dalam Mengantisipasi Perubahan Iklim Global. 45-53.

Selino, A. and M.D. Jones. 2013. Large and small eddies matter: Animating trees in wind using coarse fluid simulation and synthetic turbulence. Computer Graphics Forum, 32: 75-84.

Soares, P.M.M., D.C.A. Lima, R.M. Cardoso, M.L. Nascimento, and A. Semedo. 2017. Western Iberian offshore wind resources: More or less in a global warming climate?. Applied Energy, 203: 72-90.

Sridevi, V. and V. Chellamuthu. 2015. Impact of weather on rice - A review. International Journal of Applied Research, 1: 825-831.

Tadrist, L., K. Julio, M. Saudreau and E. de Langre. 2015. Leaf flutter by torsional galloping: Experiments and model. Journal of Fluids and Structures, 56: 1-10.

United Nations. 2017. UN agriculture agency takes step to help rice farmers bolster production. https://news.un.org/en/story/2017/03/.

Virot, E., A. Ponomarenko, E. Dehandschoewercker, D. Quere, and C. Clanet. 2016. Critical wind speed at which trees break. Physical Review E., 93: 023001. 
Wang, F., F. Cheng, and G. Zhang. 2007. Difference in grain yield and quality among tillers in rice genotypes differing in tillering capacity. Rice Science, 14: 135-140.

Wu, W. and B.L. Ma. 2016. A new method for assessing plant lodging and the impact of management options on lodging in canola crop production. Scientific Reports, 6: 31890.
Zhu, Y. and C. Shao. 2017. The steady and vibrating status of tulip tree leaves in wind. Theoretical and Applied Mechanics Letters, 7: 30-34. 